\title{
Dynamics of Core Inflation, Energy Inflation, Food Inflation and Manufacturing Sector Output Growth in Kenya: Econometric Analysis of Causality and Effects
}

\author{
Dr. Alphonce Juma Odondo \\ Department of Economics \\ Tom Mboya University College, a constituent College of Maseno University, Kenya
}

\begin{abstract}
World over, the manufacturing sector plays an important role in spurring economic development by boosting employment opportunities for semi-skilled labour and building a nation's competitiveness through exports. Globally, only a few nations have managed to realize their development status without manufacturing sector playing a leading role. Kenya has not managed to develop a robust manufacturing sector and its growth has been majorly ascribed to the agricultural and service sectors. It has therefore, experienced de industrialization as evidenced by the decline in GDP contribution by the manufacturing sector from a paltry $10 \%$ in 2018 to $9.7 \%$ in 2019. The de industrialization has been characterized by fluctuating inflation rates, a scenario that has elicited debate as to whether there exists any nexus between manufacturing sector output growth and inflation rate. A few empirical studies have been conducted on the same, however, the exact relationship is not well defined. Furthermore, inflation has been largely treated as an aggregate, a scenario that hampers policy formulation. A disaggregated approach to the analysis thus motivated this study. Time series data from the world bank was used and VECM estimated to assess long run dynamics after stationarity test by ADF and Cointegration test by Johannes's approach. Short run causalities were assessed via Wald test. The study revealed long run relationship between manufacturing output growth and the variables (core inflation, energy inflation and food inflation). Short run causality running from each of the inflation types to manufacturing output growth also exists. Food inflation negatively and significantly influences manufacturing output growth while core inflation has significant positive effect on the same. To enhance manufacturing output growth in Kenya, food inflation should be reduced and stabilized. In the same vain, low and stable level of core inflation should be ensured over time.
\end{abstract}

Keywords: Inflation, Manufacturing Sector, Dynamics, Econometrics, Causality, Kenya

DOI: $10.7176 / \mathrm{JESD} / 12-2-05$

Publication date: January $31^{\text {st }} 2021$

\section{Introduction}

Globally, the manufacturing sector plays a significant role in spurring economic development by enhancing and sustaining high productive growth, boosting employment opportunities for semi-skilled labour and building country's competitiveness through exports (KAM, 2018; Signe and Johnson, 2018). Across the world, just a few nations have managed to attain their development status without manufacturing sector taking the lead. Like many other developing economies, Kenya has not managed to develop a robust manufacturing sector (Walter, Ikiara and Begumisa, 1991), and its growth has been largely driven by the agricultural and service sectors (KAM 2018). It has therefore, experienced de industrialization as shown by the decline in GDP contribution by the manufacturing sector from a paltry 10\% in 2018 down to $9.7 \%$ in 2019 (Cytonn, 2020). The Country's de industrialization has been characterized by fluctuating core, energy and food inflation rates, a scenario that has elicited debate as to whether there exists any perceptible relationship between the manufacturing sector output growth and the inflation rates (World Bank, 2020).

Improving outcomes in the manufacturing sector remains an important strategy for the Kenya Government as evidenced by the Vision 2030, the Kenya Industrial Transformation Programme (KITP) and the Big 4 initiatives which have all been designed to revamp the manufacturing sector (GoK, 2007; KAM 2018). As alluded to in the Kenya's Medium Term Plan 3, the declining proportion of the manufacturing sector in the Gross Domestic Product poses a major challenge to economic growth (Were, 2016). Thus an investigation into the relationship between the manufacturing sector output growth and potential determinants such as inflation rates is imperative.

In economic sense, inflation denotes a general increase in prices and fall in the purchasing value of money, and if not checked can be injurious to an economy (Costantino, Lionel and Millicent, 2007). Core inflation represents the long run trend in the price levels. In measuring the long run inflation, transitory price variations particularly for items like food and energy whose prices are generally volatile are excluded. According to Shankar (2019), food inflation refers to increase in the wholesale price index of a basic food item relative to the general index or the consumer price index (CPI). In the developed countries, the rise in food prices causes a small inconvenience, something to groan about while in developing countries, the citizens may not get sufficient amounts to consume and might as well starve for food. This type of inflation is quite volatile and its volatility depends on 
agricultural prices as the change in weather, supply, and demand in the agricultural sector tend to vary (Shankar, 2019). Energy inflation on the other hand refers to the inflation ascribed to the contribution of energy prices (Rubene, 2018). Most production activities are generally dependent on energy whose consumption is determined by its price among other factors. The prices impact on the cost of production which is further transferred to the consumers in the form of commodity prices along the production to consumption systems of the item (Durevall and $\mathrm{Sjö}, 2012$ ).

An empirical study by Gouhau (2017) in China on the relationship between agricultural product price fluctuation and inflation revealed that there was no co-integration relationship between agricultural product price fluctuation and inflation. However, agricultural product price fluctuation Granger caused inflation expectation. On the other hand, Gokal and Hanif (2004) who looked at the relationship between inflation and economic growth in China noted a weak negative correlation between inflation and economic growth, and that there was one-way causality running from GDP growth to inflation. The results contradicted Sindano (2014) who did a similar study in Namibia and established a bi directional causality between economic growth and inflation. In Tanzania, a study by Kazidi and Mwakanemela (2013) showed that there was no co-integration between inflation and economic growth. The varying findings are supported by Akinsola and Odhiambo (2017) who aver that the impact of inflation on economic growth differs with the countries over time because of the differences in their characteristics, data set, and methods of analyses employed.

Modebe and Ezeaku (2016) argued that relations between inflation and economic growth have largely been investigated at an aggregate level and the need to relate inflation to some specific sectors of an economy was necessary. Their study hence focused on the linkage between inflation and manufacturing sector growth in Nigeria. The study revealed that inflation had a negative and non-significant effect on manufacturing sector growth and that no causal relationship existed between inflation and output growth. These findings however, slightly differed with those of Bans-Akutey, Deh and Mohammed (2016), who used annual time series data for Ghana and established significant stable long run relationship between inflation and manufacturing sector productivity. However, the estimated Vector Error Correction Model revealed insignificant short run link between inflation and manufacturing sector productivity.

From the foregoing literature, it is overt that empirical studies have been carried out on the nexus between inflation and economic growth indicators which include among others the manufacturing growth. Nevertheless, the exact relationship is not well defined as there are varying results. Furthermore, inflation has been largely treated as an aggregate, a scenario that hampers formulation of specific policies for economic growth. A disaggregated approach to the analysis of the relationship between inflation and manufacturing growth is therefore necessary and forms the basis for this study. This study was based on the classical theory of growth in which it is implicitly asserted that there is a negative relationship between Economic growth and inflation (Akinsola and Odhiambo, 2017).

\subsection{Research Methodology}

\subsection{Research Philosophy and design}

The study was guided by the positivists philosophy. Positivism follows the interpretation that only factual knowledge acquired through observation and measurement is reliable. As a philosophy, it is line with the empiricist view that knowledge stems from human experience and observed facts of life (Collins, 2010). Moreover, the researcher is independent from the study and there is no room for human interests within the study. As a rule, and on average, positivist studies do follow a deductive approach and that the researcher needs to concentrate on facts (Crowther and Lancaster, 2008). In order to realize the set objective for the study, correlational research design was adopted. The design is suitable for studies that seek to establish relationships Glenn and Glen (2005).

\subsection{Study area}

This study was conducted in Kenya which is located at the latitude of $0.0236^{\circ} \mathrm{S}$, and longitude of $37.9062^{\circ} \mathrm{E}$. The GPS coordinates of Kenya show that the country is bisected by the equator and approximately half of it is in the northern hemisphere. The country's total area is approximately 224,080 square miles. Including all fourty-seven distinct counties, the total area is $98 \%$ land and $2 \%$ water. In numbers, these percentages equate to 219,745 square miles of land and 4,335 square miles of water. The geography of Kenya spans for a width of 374.03 miles and a length of 485.51 miles. Currently, the population is approximately 51,629,122 people (United Nations, 2019). Figure 1 shows the map of Kenya and its geographical location 


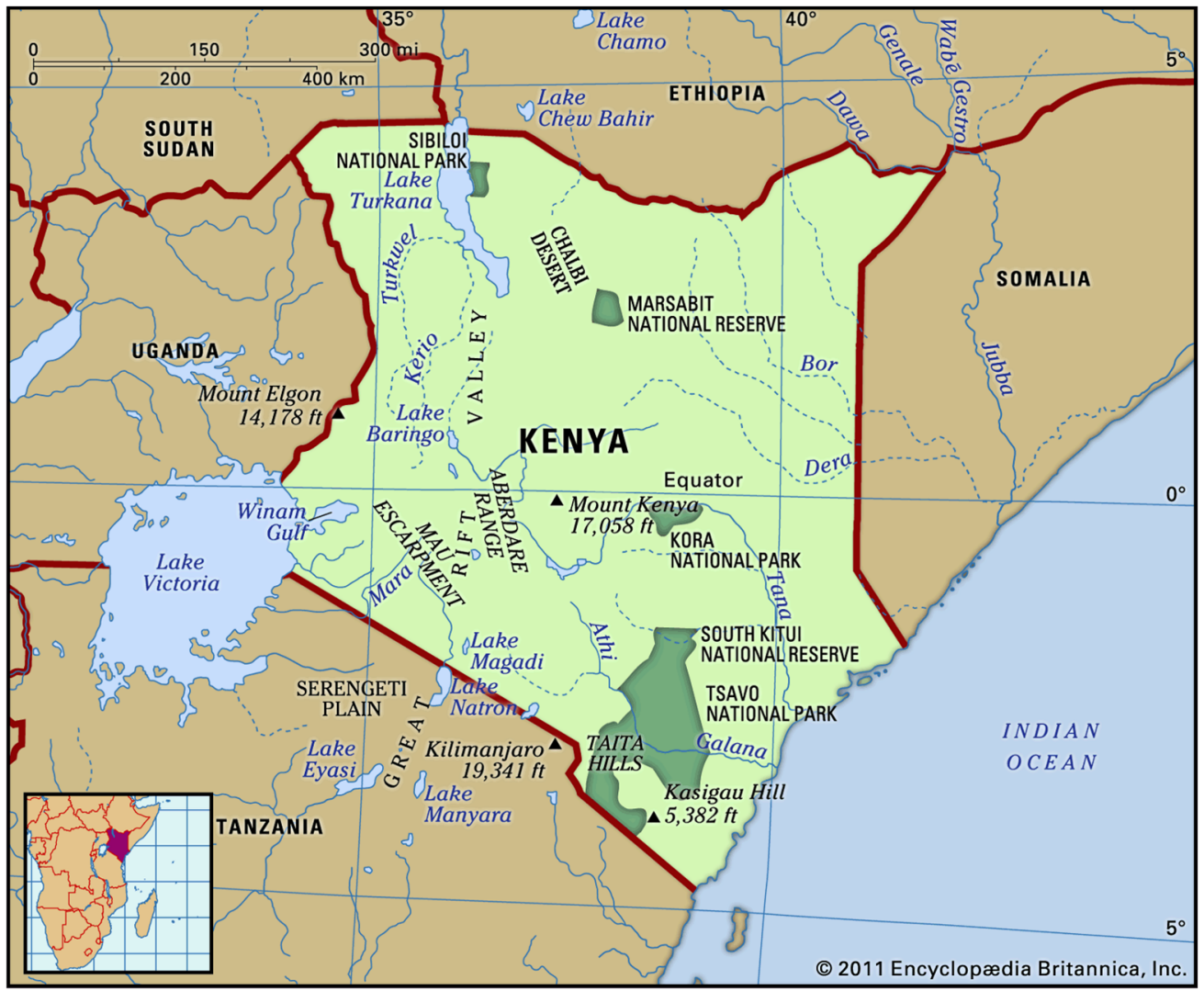

Figure 1: The map of Kenya and its geographical location.

\subsection{Data type and data sources}

The study used monthly time series data from the World Bank, based on the data from Kenya National Bureau of Statistics which covered January 2017 to February 2020. The dependent variable was manufacturing growth while the independent variables were the dimensions of inflation which embraces: core inflation rate, food inflation rate and energy inflation rate.

\subsection{Model Specification}

Based on classical theory of economic growth, the functional relationship between the variables was expressed in its implicit form as shown in Equation 1

$M G R=f(C R, F R, E R)$ Equation 1

Stochastic form of the model was then specified as shown in Equation 2 below;

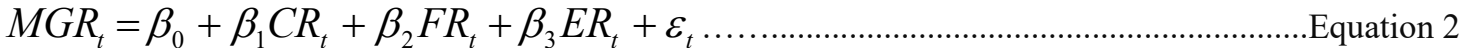

Where: $\mathrm{MGR}=$ Manufacturing output growth rate, $\mathrm{CR}=$ Core inflation, $\mathrm{FR}=$ food inflation, $\mathrm{ER}=$ energy inflation, $\beta_{0}=$ Constant term; $\beta_{1,} \beta_{2}, \beta_{3}$, are parameter estimates; $\varepsilon_{t}=$ error term which is assumed to be $N\left(\mu, \delta^{2}\right)$

\subsection{Data Analysis}

The data were first subjected to unit root test for stationarity. This was undertaken as a precautionary measure against estimation of spurious regression models (Gujarat, 2004; Datta and Kumar, 2011). The analysis was done using Augmented Dickey-Fuller test on the basis of a null hypothesis that the time series were non stationary (i.e. $\delta=0$ ) and alternative hypothesis that the time series were stationary (i.e. $\delta \neq 0$ ). The general form of ADF according to Bierens and Guo (1993) is specified as $Y_{t}=\psi Y_{t-1}+\mu_{t} \ldots \ldots$ Equation 3

Where: if $\psi<1$, then $Y$ is stationary otherwise if $\psi=1$, unit root exists suggesting that $Y$ is non stationary. According to Green 2002, if data is non stationary, stationarity can be achieved by differencing the data set. This can be realized by having a one period lag of the $\mathrm{Y}$ variable and subtracting it from both sides of Equation 3 to yield Equation 4 specified as:

$Y_{t}-Y_{t-1}=(\psi-1) Y_{t-1}+\mu_{t}$ Equation 4 
Equation 4 is then re specified as: $\Delta Y_{t}=\delta Y_{t-1}+\mu_{t} \ldots \ldots \ldots \ldots \ldots \ldots \ldots \ldots \ldots \ldots \ldots \ldots \ldots$ Equation 5

Where $\delta=(\psi-1)$ and $\Delta$ is the difference operator. Equation 5 is then tested for the null hypotheses. As alluded in Mobede and Ezeaku (2016), Kasidi and Mwakanemela (2013), and Ssekuma (2011), the actual testing procedure for the ADF unit root test is illustrated in Equation 6 stated as

$\Delta Y_{t}=\beta_{0}+\beta_{1} t+\psi Y_{t-1}+\sum_{j=1}^{k} \delta_{j} \Delta Y_{t-j}+\mu_{t} \ldots \ldots \ldots \ldots \ldots \ldots$. Equation 6

Where: $\beta_{0}$ is a constant, $\beta_{1}$ is the coefficient on a time trend series, $\psi$ is a coefficient which measures the unit root, $k$ is the lag order of the autoregressive process, $\delta_{j}$ is a measure of lag length, $\Delta Y_{t}=Y_{t}-Y_{t-1}$ are the first differences of $Y_{t}, Y_{t-1}$ are lagged values of order one of $Y_{t}, \Delta Y_{t-j}$ are changes in lagged values and $\mu_{\mathrm{t}}$ is the white noise which is assumed to be normally distributed with zero mean and constant variance.

As explained by Hjalmarsson and Osterholm (2007), Johansen test for co-integration was employed to determine if the study variables (Core inflation, energy inflation and food inflation) had long-run association, or co-integrated. The general form of Johansen's methodology takes its starting point in a VAR of order $\ell$ given as:

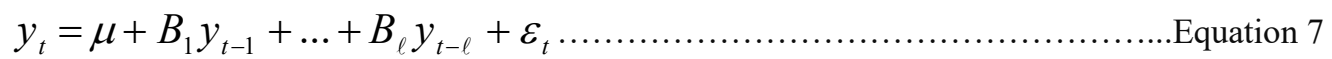

$y_{t}$ is an nx 1 vector of variables that are integrated of order one while $\varepsilon_{t}$ is an nx1vector of innovations. Vector Error Correction Model was used to establish the possible dynamic effects of the explanatory variables on the explained variable (Green, 2002), while the Wald test was conducted to determine the nature of short run causal relationships.

\subsection{Results and Discussions \\ 3.1 Unit Root Tests}

Stationarity of time series data is of immense importance to econometricians and statisticians because it influences how the data is perceived and predicted (Green, 2002). For stationarity of data to be achieved, the classical properties of a system should not vary over time. This implies that the overall behavior of the data set should remain constant (Gujarat, 2004). The researcher therefore tested for the stationary of the data set used in the study using Augmented Dickey-Fuller test.

As a rule of thumb, since the null hypothesis assumes the presence of unit root, the p-value obtained should be less than the significance level (e.g. 0.05) for the rejection of the null hypothesis, thereby inferring that the series is stationary. Otherwise if the p-value is greater than the significance level (e.g. 0.05), we conclude that unit root exists thus, the series is non stationary. Similarly, if the absolute value of the test statistics is less than the critical value, we infer that unit root exists and therefore the series is non stationary. Table 1 shows the unit root test results for the series before first difference. Based on the outlined rule of thumb, it is overt that the data sets for CR, ER, FR and the MRG have a unit root. The p-values obtained for each data set is greater than the $5 \%$ which was set as the significance level for the study. Similarly, the absolute value of the ADF test statistics for each of the variables is less than the corresponding absolute value of the test statistics at $5 \%$ level of significance. The study thus concludes that the series are non stationary at levels.

Table 1 Unit Root Test of the variables before $1^{\text {st }}$ Difference

\begin{tabular}{|c|c|c|c|c|c|c|}
\hline \multirow[b]{2}{*}{ Variable } & \multicolumn{5}{|c|}{ Augmented Dickey-Fuller test statistics } & \multirow[b]{2}{*}{ Observation } \\
\hline & At levels & p-value & $1 \%$ & $5 \%$ & $10 \%$ & \\
\hline CR & -0.218409 & 0.9272 & -3.621023 & -2.943427 & -2.610263 & Unit root exists \\
\hline ER & -1.159506 & 0.6810 & -3.626784 & -2.945842 & -2.611531 & Unit root exists \\
\hline FR & -1.251528 & 0.6414 & -3.621023 & -2.943427 & -2.610263 & Unit root exists \\
\hline MRG & -1.948511 & 0.3074 & -3.621023 & -2.943427 & -2.610263 & Unit root exists \\
\hline
\end{tabular}

Key: MGR $=$ manufacturing growth rate, $\mathrm{CR}=$ core inflation, $\mathrm{FR}=$ food inflation, $\mathrm{ER}=$ energy inflation

Source: Author's computations (2020)

Table 2 shows the unit root test results for the series at first difference. From Table 2 we can deduce that unit root does not exist in each of the series at first difference since the p-values are less than $5 \%$ level of significance. The deduction is further supported by the absolute value of the ADF test statistics for each of the variables which is more than the corresponding absolute value of the test statistics at $5 \%$ level of significance. The study thus concludes that the series are stationary at first difference. 
Table 2. Unit Root Test of the variables at $1^{\text {st }}$ Difference

\begin{tabular}{lllcccl}
\hline & \multicolumn{7}{l}{ Augmented Dickey-Fuller test statistics } & & \\
\cline { 2 - 6 } Variable & At levels & p-value & $1 \%$ & $5 \%$ & $10 \%$ & Observation \\
\hline D(CR) & -3.748057 & 0.0076 & -3.639407 & -2.951125 & -2.614300 & No unit root \\
D(ER) & -4.172795 & 0.0024 & -3.626784 & -2.945842 & -2.611531 & No unit root \\
D(FR) & -5.017574 & 0.0002 & -3.626784 & -2.945842 & -2.611531 & No unit root \\
D(MRG) & -5.493468 & 0.0001 & -3.626784 & -2.945842 & -2.611531 & No unit root \\
\hline
\end{tabular}

Key: $\mathrm{MGR}=$ manufacturing growth rate, $\mathrm{CR}=$ core inflation, $\mathrm{FR}=$ food inflation, $\mathrm{ER}=$ energy inflation

Source: Author's computations (2020)

Table 3 shows the lag order selection criteria for the study variables. Both the Schwarz information criterion and Hannan-Quinn information criterion show that the preferred lag length was one (1) while the LR and Final prediction error suggested lag two (2). Akaike information criterion on the other hand indicated lag four (4). According to Liew (2004), Akaike's information criterion (AIC) is preferred to other criteria in case of a sample that is less or equal to sixty (60) observations. Since the observations in this study were less than sixty, the AIC criterion was adopted.

Table 3. VAR Lag Order Selection Criteria for the study variables

\begin{tabular}{ccccccc}
\hline \hline Lag & LogL & LR & FPE & AIC & SC & HQ \\
\hline \hline 0 & -303.1417 & NA & 825.2764 & 18.06716 & 18.24673 & 18.12840 \\
1 & -187.4619 & 197.3362 & 2.364872 & 12.20364 & $13.10150^{*}$ & $12.50984^{*}$ \\
2 & -167.8266 & $28.87546^{*}$ & $1.993595^{*}$ & 11.98980 & 13.60594 & 12.54095 \\
3 & -155.5641 & 15.14771 & 2.778256 & 12.20965 & 14.54409 & 13.00576 \\
4 & -135.5577 & 20.00644 & 2.764674 & $11.97398^{*}$ & 15.02670 & 13.01505 \\
\hline \hline
\end{tabular}

* indicates lag order selected by the criterion

LR: sequential modified LR test statistic (each test at 5\% level)

FPE: Final prediction error

AIC: Akaike information criterion

SC: Schwarz information criterion

HQ: Hannan-Quinn information criterion

Source: Author's computations (2020)

\subsection{Co integration test}

Having done the Unit root tests both before and at first difference, the data were subjected to Johansen's cointegration tests where the Trace statistic and Maximum Eigenvalue were computed. Based on the Trace statistics and Maximum Eigen Statistics as captured in Table 4 and Table 5 respectively, there were three (3) cointegrating equations at $5 \%$ level of significance. When study variables are co integrated, it is advisable to estimate a vector error correction model (VECM) Brockwell and Davis (2016).

Table 4, Unrestricted Cointegration Rank Test (Trace)

\begin{tabular}{|c|c|c|c|c|}
\hline $\begin{array}{l}\text { Hypothesized } \\
\text { No. of CE(s) }\end{array}$ & Eigenvalue & $\begin{array}{c}\text { Trace } \\
\text { Statistic }\end{array}$ & $\begin{array}{c}0.05 \\
\text { Critical Value }\end{array}$ & Prob.** \\
\hline None $*$ & 0.865271 & 139.2212 & 47.85613 & 0.0000 \\
\hline At most $1 *$ & 0.796309 & 73.07306 & 29.79707 & 0.0000 \\
\hline At most $2 *$ & 0.463099 & 20.56509 & 15.49471 & 0.0079 \\
\hline At most 3 & 0.001242 & 0.041014 & 3.841466 & 0.8395 \\
\hline
\end{tabular}

Trace test indicates 3 cointegrating eqn(s) at the 0.05 level

* denotes rejection of the hypothesis at the 0.05 level

**MacKinnon-Haug-Michelis (1999) p-values

Source: Author's computations (2020) 
Table 5. Unrestricted Cointegration Rank Test (Maximum Eigenvalue)

\begin{tabular}{ccccc}
\hline \hline $\begin{array}{c}\text { Hypothesized } \\
\text { No. of CE(s) }\end{array}$ & Eigenvalue & $\begin{array}{c}\text { Max-Eigen } \\
\text { Statistic }\end{array}$ & $\begin{array}{c}0.05 \\
\text { Critical Value }\end{array}$ & Prob.** \\
\hline \hline None * & 0.865271 & 66.14809 & 27.58434 & 0.0000 \\
At most 1 & 0.796309 & 52.50798 & 21.13162 & 0.0000 \\
At most 2 & 0.463099 & 20.52407 & 14.26460 & 0.0045 \\
At most 3 & 0.001242 & 0.041014 & 3.841466 & 0.8395 \\
\hline \hline
\end{tabular}

Max-eigenvalue test indicates 3 cointegrating eqn(s) at the 0.05 level

* denotes rejection of the hypothesis at the 0.05 level

**MacKinnon-Haug-Michelis (1999) p-values

Source: Author's computations (2020)

Table 6 shows the VECM that was estimated based on the existence of the cointegrating equations. The dependent variable was manufacturing growth (MRG) while the independent variables were core inflation (CR), energy inflation (ER) and food inflation (FR). The error correction term $(C(1)=-1.816019, p=0.0001)$, which indicates that the speed of adjustment towards equilibrium is negative and statistically significant. This implies that a long run causality running from core inflation (CR), energy inflation (ER) and food inflation (FR) to manufacturing growth (MRG) exists. These results are in tandem with Bans-Akutey, Deh and Mohammed (2016) who established a significant long run relationship between inflation and manufacturing sector productivity in Ghana. It however differs with Modebe and Ezeaku (2016) who found negative but insignificant effect of inflation on manufacturing sector growth in Nigeria.

Table 6. Vector Error Correction Model (VECM) and the System Equation

Dependent Variable: D(MRG)

Method: Least Squares

Sample (adjusted): 638

Included observations: 33 after adjustments

$\mathrm{D}(\mathrm{MRG})=\mathrm{C}(1) *(\mathrm{MRG}(-1)-0.0793534783303 * \mathrm{FR}(-1)-16.9707958895)+\mathrm{C}(2) * \mathrm{CR}(-1)+$ $0.315133143769 * \mathrm{FR}(-1)-18.4077143505)+\mathrm{C}(3) *(\mathrm{ER}(-1)+1.20894959039 * \mathrm{FR}(-1)-36.8051566491)+$ $\mathrm{C}(4) * \mathrm{D}(\mathrm{MRG}(-1))+(5) * \mathrm{D}(\mathrm{MRG}(-2))+\mathrm{C}(6) * \mathrm{D}(\mathrm{MRG}(-3))+\mathrm{C}(7) * \mathrm{D}(\mathrm{MRG}(-4))+\mathrm{C}(8) * \mathrm{D}(\mathrm{CR}(-1))+$ $\mathrm{C}(9) * \mathrm{D}(\mathrm{CR}(-2))+\mathrm{C}(10) * \mathrm{D}(\mathrm{CR}(-3))+\mathrm{C}(11) * \mathrm{D}(\mathrm{CR}(-4))+\mathrm{C}(12) * \mathrm{D}(\mathrm{ER}(-1))+\mathrm{C}(13) * \mathrm{D}(\mathrm{ER}(-2))+\mathrm{C}(14) * \mathrm{D}(\mathrm{ER}(-$ $3))+\mathrm{C}(15) * \mathrm{D}(\mathrm{ER}(-4))+\mathrm{C}(16) * \mathrm{D}(\mathrm{FR}(-1))+\mathrm{C}(17) * \mathrm{D}(\mathrm{FR}(-2))+\mathrm{C}(18) * \mathrm{D}(\mathrm{FR}(-3))+\mathrm{C}(19) * \mathrm{D}(\mathrm{FR}(-4))+\mathrm{C}(20)$

\begin{tabular}{crrrr}
\hline \hline & Coefficient & Std. Error & t-Statistic & Prob. \\
\hline \hline C(1) & -1.816019 & 0.333092 & -5.452005 & 0.0001 \\
C (2) & -6.673251 & 1.386693 & -4.812349 & 0.0003 \\
C(3) & 0.131304 & 0.213856 & 0.613983 & 0.5498 \\
C(4) & 0.831705 & 0.291691 & 2.851320 & 0.0136 \\
C(5) & 0.995705 & 0.248021 & 4.014595 & 0.0015 \\
C(6) & 0.514427 & 0.208881 & 2.462780 & 0.0285 \\
C(7) & 0.582143 & 0.166241 & 3.501808 & 0.0039 \\
C(8) & 6.122202 & 2.403665 & 2.547028 & 0.0243 \\
C(9) & 5.205737 & 2.763369 & 1.883837 & 0.0821 \\
C(10) & 3.997838 & 2.944681 & 1.357647 & 0.1977 \\
C(11) & 8.969645 & 2.999911 & 2.989970 & 0.0104 \\
C(12) & 0.498791 & 0.294639 & 1.692893 & 0.1143 \\
C(13) & 0.519807 & 0.388632 & 1.337530 & 0.2040 \\
C(14) & -0.794812 & 0.358904 & -2.214551 & 0.0453 \\
C(15) & 0.008703 & 0.360275 & 0.024156 & 0.9811 \\
C(16) & 1.333881 & 0.404366 & 3.298702 & 0.0058 \\
C(17) & 0.311092 & 0.300432 & 1.035485 & 0.3193 \\
C(18) & 0.258879 & 0.226798 & 1.141449 & 0.2743 \\
C(19) & -0.620123 & 0.218749 & -2.834866 & 0.0141 \\
C(20) & 0.560910 & 0.347205 & 1.615503 & 0.1302 \\
\hline \hline R-squared & 0.878874 & Mean dependent var & 0.472727 \\
Adjusted R-squared & 0.701844 & S.D. dependent var & 2.761824 \\
& & & &
\end{tabular}




\begin{tabular}{lrll} 
S.E. of regression & 1.508058 & Akaike info criterion & 3.940085 \\
Sum squared resid & 29.56510 & Schwarz criterion & 4.847059 \\
Log likelihood & -45.01141 & Hannan-Quinn criter. & 4.245254 \\
F-statistic & 4.964539 & Durbin-Watson stat & 2.600055 \\
Prob(F-statistic) & 0.002529 & & \\
\hline \hline
\end{tabular}

Source: Author's computations (2020)

\subsection{Short run Causalities}

The study further employed Wald statistics to test whether or not the estimated coefficients in the VECM were significantly different from zero $\quad(i, \quad$ e. $\quad \mathrm{C}(8)=\mathrm{C}(9)=\mathrm{C}(10)=\mathrm{C}(11)=0 ; \quad \mathrm{C}(12)=\mathrm{C}(13)=\mathrm{C}(14)=\mathrm{C}(15)=0$; $\mathrm{C}(16)=\mathrm{C}(17)=\mathrm{C}(18)=\mathrm{C}(19)=0)$. The Chi-square probability corresponding to the null hypothesis on core inflation as presented in Table $7 \mathrm{a}$ is less than $5 \%$. Thus, the null hypothesis of $C(8)=C(9)=C(10)=C(11)=0$ is rejected, implying that there is short run causality running from core inflation to manufacturing growth. Similarly, the Chisquare probability corresponding to the null hypothesis on energy inflation as captured in Table $7 \mathrm{~b}$ is less than 5\%, indicating that there is short run causality running from energy inflation to manufacturing growth. In addition, the Chi-square probability corresponding to the null hypothesis on food inflation as captured in Table $7 \mathrm{c}$ is less than $5 \%$, suggesting the existence of short run causality running from food inflation to manufacturing growth. These results contradict Modebe and Ezeaku (2016) who used Granger causality approach and found no causality between manufacturing growth and inflation in Nigeria.

Table 7a. Wald Test for Core Inflation (CR) Coefficients

\begin{tabular}{lccc}
\hline \hline Test Statistic & Value & df & Probability \\
\hline \hline F-statistic & 4.126294 & $(4,13)$ & 0.0225 \\
Chi-square & 16.50518 & 4 & 0.0024 \\
\hline \hline
\end{tabular}

Null Hypothesis: $\mathrm{C}(8)=\mathrm{C}(9)=\mathrm{C}(10)=\mathrm{C}(11)=0$

Null Hypothesis Summary:

\begin{tabular}{|c|c|c|}
\hline Normalized Restriction $(=0)$ & Value & Std. Err. \\
\hline $\mathrm{C}(8)$ & 6.122202 & 2.403665 \\
\hline $\mathrm{C}(9)$ & 5.205737 & 2.763369 \\
\hline$C(10)$ & 3.997838 & 2.944681 \\
\hline $\mathrm{C}(11)$ & 8.969645 & 2.999911 \\
\hline
\end{tabular}

Restrictions are linear in coefficients.

Source: Author's computations (2020)

Table 7b. Wald Test for Energy Inflation (ER) Coefficients

\begin{tabular}{lccc}
\hline \hline Test Statistic & Value & df & Probability \\
\hline \hline F-statistic & 3.694886 & $(4,13)$ & 0.0320 \\
Chi-square & 14.77954 & 4 & 0.0052 \\
\hline \hline
\end{tabular}

Null Hypothesis: $\mathrm{C}(12)=\mathrm{C}(13)=\mathrm{C}(14)=\mathrm{C}(15)=0$

Null Hypothesis Summary:

\begin{tabular}{lcc}
\hline \hline Normalized Restriction $(=0)$ & Value & Std. Err. \\
\hline \hline $\mathrm{C}(12)$ & $=0.498791$ & 0.294639 \\
$\mathrm{C}(13)$ & 0.519807 & 0.388632 \\
$\mathrm{C}(14)$ & -0.794812 & 0.358904 \\
$\mathrm{C}(15)$ & 0.008703 & 0.360275 \\
\hline \hline
\end{tabular}

Restrictions are linear in coefficients.

Source: Author's computations (2020) 
Table 7c. Wald Test for Food Inflation (FR) Coefficients

\begin{tabular}{lccc}
\hline \hline Test Statistic & Value & df & Probability \\
\hline \hline F-statistic & 6.224855 & $(4,13)$ & 0.0050 \\
Chi-square & 24.89942 & 4 & 0.0001 \\
\hline \hline
\end{tabular}

Null Hypothesis: $C(16)=C(17)=C(18)=C(19)=0$

Null Hypothesis Summary:

\begin{tabular}{lcc}
\hline \hline Normalized Restriction $(=0)$ & Value & Std. Err. \\
\hline \hline $\mathrm{C}(16)$ & 1.333881 & 0.404366 \\
$\mathrm{C}(17)$ & 0.311092 & 0.300432 \\
$\mathrm{C}(18)$ & 0.258879 & 0.226798 \\
$\mathrm{C}(19)$ & -0.620123 & 0.218749 \\
\hline \hline
\end{tabular}

Restrictions are linear in coefficients.

Source: Author's computations (2020)

Table 8 shows the Long run OLS baseline model with an explanatory power of 0.568245 , suggesting that $56.8245 \%$ changes in the manufacturing growth is jointly explained by the three explanatory variables (i.e. core inflation, food inflation and energy inflation). The baseline model shows that energy inflation (ER) has insignificant negative effect on manufacturing growth $(\beta=-0.506374, p=0.1366>0.05)$ while food inflation has significant negative effect on manufacturing growth $(\beta=--1.046668, p=0.0000<0.05)$. The negative relationship is a likely indicator that the higher the food and energy inflation rate, the lower is the manufacturing growth ceteris paribus. This result conforms to the classical economic theory which implicitly indicates that there is a negative relationship between inflation rate and economic growth (Akinsola and Odhiambo, 2017). Manufacturing sector is one of the important sectors that contribute significantly to the Kenya's economy (GoK, 2007; KAM 2018), therefore, whatever impacts negatively to its growth could have a negative impact on the economy's GDP. A number of studies such as Modebe and Ezeaku (2016), Gokal and Hanif (2004), and (Quartey, 2010) that have focused on the relationship between inflation and economic growth support these findings. On the contrary, the study revealed a positive significant relationship between core inflation and manufacturing growth $(\beta=3.231256$, $p=0.0000<0.05$ ). This finding agrees with Mubarik (2005), who aver that the nexus between inflation and economic growth remains inconclusive and that low but stable inflation enhances economic growth and vice versa. This result is further armored by the visual impression created in Figure 2 where the core inflation appears low and stable over time unlike the case of food inflation and energy inflation.

Table 8. Long Run Ordinary Least Squares (OLS) Base line Model

Dependent Variable: MRG

Method: Least Squares

Included observations: 38

\begin{tabular}{rrrrr}
\hline \multicolumn{1}{r}{ Variable } & Coefficient & Std. Error & t-Statistic & Prob. \\
\hline \hline ER & -0.506374 & 0.332355 & -1.523592 & 0.1366 \\
CR & 3.231256 & 0.659377 & 4.900466 & 0.0000 \\
FR & -1.046668 & 0.206803 & -5.061193 & 0.0000 \\
\hline \hline R-squared & 0.568245 & Mean dependent var & & 16.63684 \\
Adjusted R-squared & 0.543573 & S.D. dependent var & & 7.024914 \\
S.E. of regression & 4.745986 & Akaike info criterion & & 6.028132 \\
Sum squared resid & 788.3534 & Schwarz criterion & & 6.157415 \\
Log likelihood & -111.5345 & Hannan-Quinn criter. & & 6.074130 \\
Durbin-Watson stat & 0.540753 & & \\
\hline \hline
\end{tabular}

Source: Author's computations (2020) 


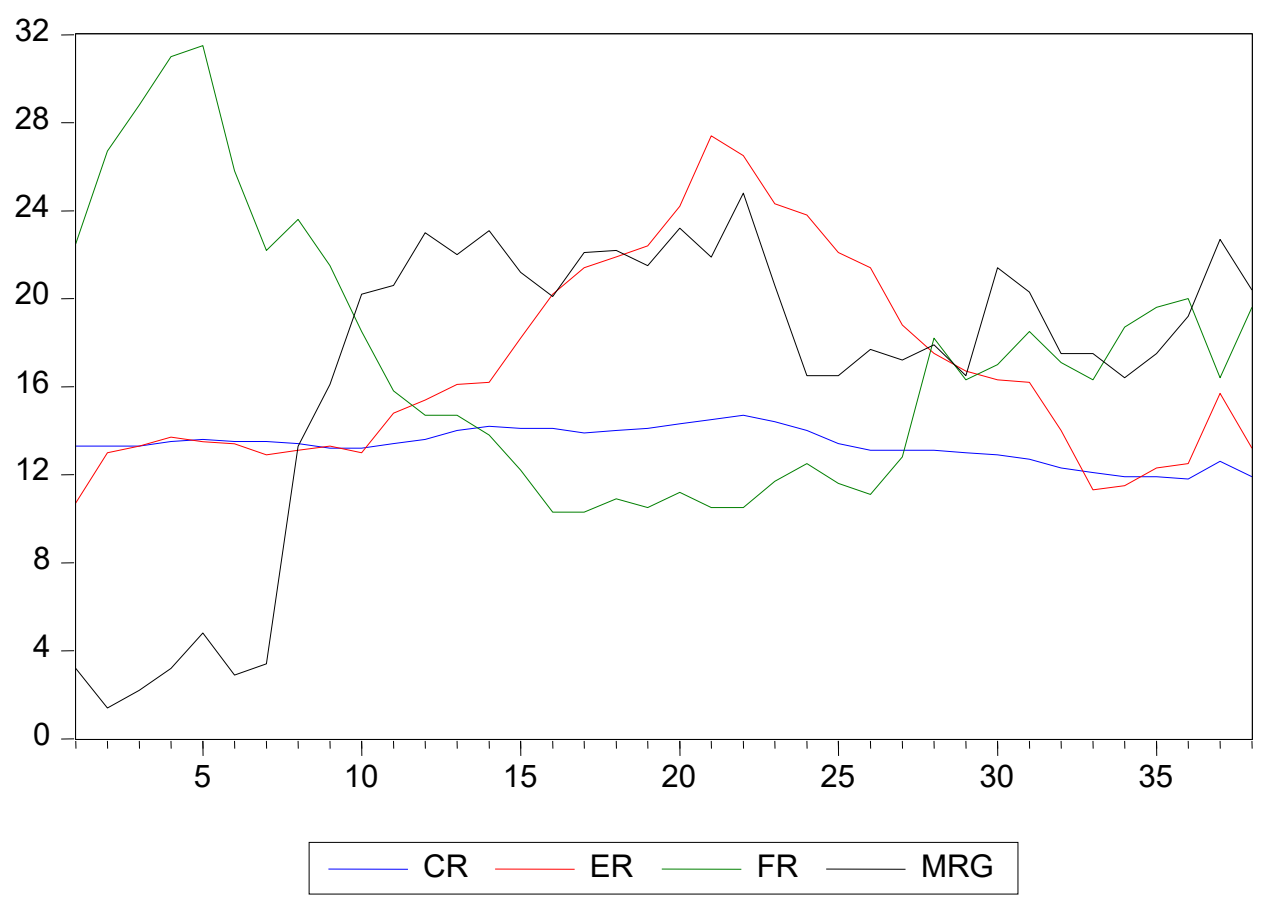

FIGURE 2: RELATIONSHIP BETWEEN INFLATION TYPES AND MANUFACTURING GROWTH

Note: Y- axis represent $\%$ rate after adjustments to take care of negative values $\mathrm{X}$-axis represents the monthly observations from Jan 2017 to Feb 2020

\subsection{Conclusion and Recommendations}

Manufacturing sector contributes significantly to the Kenya's economy and is influenced by a number of factors as noted by several authors. In this study, the estimated vector error correction model (VECM) has revealed along run relationship between manufacturing growth and all the aspects of inflation (i.e. core inflation, energy inflation and food inflation). This implies that even with the short run dynamics, long run equilibrium exists between manufacturing growth and the exogenous factors. In addition, there is perceptible short run causality running from each of the inflation dimensions to manufacturing growth. The Ordinary least square has also shown that food inflation negatively and significantly influences manufacturing growth while core inflation has a significant positive effect on manufacturing growth. The study therefore, concludes that there are short run dynamics and causality between the inflation dimensions and manufacturing growth. Moreover, the short run dynamics adjust overtime leading a long run equilibrium between manufacturing growth and the exogenous variables under study.

To enhance manufacturing growth in Kenya ceteris paribus, the study recommends that food inflation should be reduced and stabilized. Low and stable level of core inflation should also be ensured over time.

\section{Acknowledgement}

I wish to acknowledge Tom Mboya University College particularly the Library and the ICT departments for providing the necessary literature and creating enabling research environment that helped in completing this work. I extend my appreciation to the Management of Tom Mboya University College and the entire Faculty of Business and Economics for their cooperation while doing this work.

\section{References}

Akinsola F. A. and Odhiambo N. M. (2017). Inflation and Economic Growth: A Review of the International Literature, Comparative Economic Research, 20, (3), 42-56.

Bans-Akutey M., Deh W., and Mohammed F. (2016). What is the effect of Inflation on Manufacturing Sector Productivity in Ghana? MPRA PP No. 75145.

Bierens, H.J. and Guo S. (1993), "Testing for Stationarity and Trend Stationarity Against the Unit Root Hypothesis," Econometric Reviews, 12: 1-32.

Brockwell P.J and Davis R.A.(2016). Introduction to Time Series and Forecasting (Springer Texts in Statistics) $3^{\text {rd }}$ Edition.

Collins, H. (2010) "Creative Research: The Theory and Practice of Research for the Creative Industries" AVA Publications, p.38

Crowther, D. \& Lancaster, G. (2008) "Research Methods: A Concise Introduction to Research in Management 
and Business Consultancy" Butterworth-Heinemann

Costantino B., Lionel R. R., and Millicent E. S. (2007). Economics of Inflation: A Study of Currency Depreciation in Post-War Germany, George Allen \& Unwin Publishers, London. Sir Halley Stewart Publications.

Cytonn Investment (2020). Kenya Macro Economic Review Report.

Datta, K. and Kumar, C. (2011). Relationship between Inflation and Economic Growth in Malaysia. International Conference on Economics and Finance Research IPEDR, 14 (2), 415-16.

Durevall. D and Sjö.B. (2012). The Dynamics of Inflation in Ethiopia and Kenya. African Development Bank Group, Working Paper No. 151. 2012.

Glenn H and Glen M.H ( 2005). Research Methods for Massage and Holistic Therapies-eBook.

GoK. (2007). Government of the Republic of Kenya, Vision 2030.

Gokal, V., Hanif, S. (2004), Relationship between Inflation and Economic Growth. Working Paper 2004/04.

Greene, H. (2002). Econometric Analysis, $5^{\text {th }}$ ed. New Jersey: Prentice Hall- Upper Saddle River.

Gujarati, N. (2004). Basic Econometrics. $4^{\text {th }}$ ed. New York: The McGraw-Hill.

Guohua G. (2017). The Study on the Relationship between Agricultural Product Price Fluctuation and Inflation Journal of Service Science and Management, 10 (2), 166-176.

Hjalmarsson, E. and Osterholm, P. (2007). Testing for Co-integration Using the Johansen Methodology when Variables are Near-Integrated, IMF Working Paper, 7 (141), 22-27.

Kasidi F. and Mwakanemela K. (2013). Impact of Inflation on Economic Growth: A Case Study of Tanzania, Asian Journal of Empirical Research, 3(4), 363-380.

Kenya Association of Manufacturers (KAM, 2018). Manufacturing in Kenya Under the 'Big 4 Agenda'A Sector Deep-dive Report.

Liew, V. K (2004). Which lag selection Criteria Should we employ? Economics Bulletin, 3(33), 1-9.

Modebe N. J and Ezeaku C. H. (2016). Dynamics of Inflation and Manufacturing Sector Performance in Nigeria: Analysis of Effect and Causality, International Journal of Economics and Financial Issues, 6(4), 1400-1406.

Mubarik, A. (2005). Inflation and Growth. An Estimate of the Threshold Level of Inflation in Pakistan. SBPResearch Bulletin, 1(1), 35-43.

Quartey, P. (2010). Price Stability and the Growth Maximizing rate of inflation for Ghana, Business and Economic Journal,1 (1) 180-194.

Rubene I. (2018) The role of energy prices in recent inflation outcomes: a cross-country perspective, $E C B$ Economic Bulletin, 7.

Shankar S. R. (2019). Food Inflation and Its Adverse Effects on the Economy, an article available at $<$ https://www.dittotrade.academy/education/intermediate/fundamental-analysis/fundamentalindicators/food-inflation-and-its-adverse-effects-on-the-economy/>

Sindano A. (2014). Inflation and Economic Growth: An Estimate of an Optimal Level of Inflation in Namibia, a published Master thesis, Namibia Business School.

Signé L, and Johnson C, (2018). The potential of Manufacturing and industrialization in Africa Trends, opportunities, and strategies.

Ssekuma, R. (2011). A study of Co-integration Models with Applications, University of South Africa, South Africa. United Nations (2019). World Population Prospects (2019 Revision)

Walter O., Ikiara. G.K., Begumisa G.B. (1991). "Manufacturing sector in Kenya: An empirical Analysis" Published Master of Arts Economics, University of Nairobi, Kenya.

Were A. (2016). Manufacturing in Kenya: Features, Challenges and Opportunities, a paper commissioned in Nairobi, Kenya on $29^{\text {th }}$ August2016 by the Supporting Economic Transformation Programme.

World Bank Group (2020). Kenya Economic Update, $21^{\text {st }}$ Edition. 